\title{
PENGAWASAN DPR-RI DALAM BISNIS MILITER SEBAGAI BAGIAN DARI REFORMASI TENTARA NASIONAL INDONESIA (TNI)
}

\author{
Yusa Djuyandi \\ Departemen Ilmu Politik FISIP Universitas Padjadjaran \\ E-mail: yusa.djuyandi@unpad.ac.id
}

\begin{abstract}
DPR-RI oversight in TNI (military) Business have very important role in forming of professional and reliable TNI, despitefully DPR-RI oversight also useful to link citizen priority and views in rule of policy and law in defence area. The purpose of this research is to analyze the oversight mechanism conducted by DPR-RI in the case of military business. Theory used by researcher in conducting this research is theory of parliamentary oversight, which is conducting through various mechanism which available in parliament, that is: passing debate mechanism; passing existence of commission; and through raised questions when in meeting. This research used qualitative method, and data research was obtained from primary and secondary data. Primary data was gained through observation and interview. Based on the research, the oversight mechanism have been run by first commission of DPR$R I$ was still weaken, on the other side the parliament (DPR) also lack in creating an effective oversight, where this matter because of some factors, such as: the lack of political willingness of parliamentary member, lack of positive supervision practices and the limited information had by DPR.
\end{abstract}

Key words: DPR-RI (parliament), TNI, military business, oversight

\begin{abstract}
ABSTRAK
Pengawasan DPR-RI dalam Bisnis TNI memiliki peran yang sangat penting dalam pembentukan TNI yang handal dan profesional, disamping itu pengawasan DPR juga dapat bermanfaat untuk menjembatani pandangan-pandangan dan prioritas warga negara di bidang pertahanan. Tujuan dari penelitian ini adalah untuk menganalisa pengawasan yang dilakukan DPR-RI dalam bisnis militer. Adapun teori yang digunakan dalam melakukan penelitian ini adalah teori pengawasan parlemen, yang dilakukan melalui berbagai mekanisme, yaitu: melalui mekanisme perdebatan; keberadaan komisi; dan pertanyaan-pertanyaan yang diajukan ketika dalam rapat. Metode penelitian yang digunakan adalah metode kualitatif, data penelitian terdiri dari data primer dan sekunder. Data primer dilakukan melalui teknik observasi dan wawancara. Hasil penelitian menunjukan bahwa meskipun mekanisme pengawasan telah dijalankan oleh Komisi I DPR-RI, namun pengawasan yang dilakukan masih lemah. Disisi lain DPR juga masih kurang dalam menciptakan pengawasan yang efektif, hal ini disebabkan masih belum kuatnya kemauan politik anggota Komisi I DPR-RI, masih belum terciptanya kebiasaan praktek pengawasan yang positif dan juga terbatasnya informasi yang dimiliki DPR-RI.
\end{abstract}

Kata kunci: DPR-RI, TNI, bisnis militer, pengawasan 


\section{PENDAHULUAN}

Pengawasan merupakan suatu aspek yang sangat diperlukan agar suatu rencana dapat berjalan sesuai dengan apa yang telah ditetapkan, tanpa pengawasan maka suatu rencana yang telah ditetapkan akan sulit diketahui sejauhmana perkembangan, yaitu apakah dapat memenuhi tujuan yang telah ditetapkan atau justeru sebaliknya terdapat banyak penyimpangan. Siswanto (2007: 139) menjelaskan bahwasanya pengawasan diperlukan untuk mengambil tindakan perbaikan (corrective action) secara tepat waktu apabila terjadi suatu penyimpangan dari perencanaan. Berarti dengan adanya langkah perbaikan secara tepat waktu, maka pengawasan juga bermanfaat untuk mengantisipasi terjadinya penyimpangan yang lebih jauh dari pelaksanaan sebuah kebijakan.

Dalam negara yang menganut asas demokrasi, dimana kekuasaan diyakini berada di tangan rakyat dan dijalankan sepenuhnya oleh dan atas kehendak rakyat, maka pengawasan terhadap lembaga-lembaga negara dilakukan oleh rakyat yang diwakilkan oleh lembaga legislatif (parlemen). Parlemen sebagai lembaga perwakilan rakyat yang anggota-anggotanya dipilih oleh rakyat mempunyai hak dan kewajiban untuk menjaga kepentingan rakyat serta menjalankan amanah rakyat, maka dari itu parlemen dalam menjalankan setiap aktivitasnya diberikan sejumlah fungsi termasuk diantaranya adalah fungsi pengawasan sebagaimana tercantum dalam UUD 1945 Pasal 20A ayat (1), dan UU No. 22 / 2003, Pasal 25.

Dalam konsep trias politica yang dicetuskan dan diidealkan oleh Montesquieu peranan dalam fungsi pengawasan yang dijalankan oleh lembaga legislatif atau parlemen dapat bermanfaat untuk menciptakan suatu mekanisme checks and balances, dengan adanya kondisi seperti ini maka akan terbentuk sebuah keseimbangan politik dan tidak adanya dominasi kekuasaan eksekutifatau yudikatif dalam sebuah negara. Ketika tercapai sebuah keseimbangan politik, Montesquieu sebagaimana dikutip oleh Budiardjo (2000: 153), berpendapat kondisi tersebut kemudian akan menciptakan sebuah kemerdekaan, makna dari kemerdekaan itu sendiri adalah terbebas dari pemerintahan otoriter yang bertindak sewenang-wenang terhadap rakyatnya.
Pengawasan parlemen dalam reformasi Tentara Nasional Indonesia (TNI) dilandasi oleh pentingnya menjalankan demokrasi, yaitu sebagai upaya mencegah munculnya pemerintahan yang otoriter. Pentingnya pengawasan parlemen dalam pelaksanaan refromasi TNI selain itu didasarkan juga atas dasar bahwa penyelenggaraan pertahanan seringkali menggunakan bagian yang besar dari Anggaran Pendapatan Belanja Negara (APBN), sehingga rakyat berhak tahu untuk apa anggaran itu digunakan dan sudah menjadi tugas parlemen selaku perwakilan rakyat untuk memantau penggunaan anggaran tersebut.

Walaupun TNI diletakkan sebagai alat negara dan berada dibawah struktur pemerintahan, khususnya di bawah Kemeterian Pertahanan, tetapi layaknya penyelenggaraan fungsi pemerintahan di bidang lainnya, juga dituntut adanya pengawasan parlemen selaku representasi warga negara di dalam pelaksanaan reformasi TNI.

Dari beberapa agenda reformasi TNI yang sampai saat ini masih belum sepenuhnya berjalan secara optimal, terdapat sebuah agenda reformasi TNI yang menjadi perhatian peneliti, yaitu menyangkut persoalan bisnis militer. Bisnis militer menjadi sebuah hal yang sangat penting untuk dibahas sebagai rangkaian proses reformasi TNI, sebab di dalamnya terdapat sebuah upaya untuk menjadikan TNI sebagai aktor pertahanan yang handal, profesional di bidangnya dan juga akuntabel, tetapi sayangnya pembahasan tentang bisnis militer (TNI) sampai saat ini masih belum selesai ( dalam Sukadis, 2008: 41).

Bahwa keterlibatan militer dalam aktivitas bisnis adalah aktivitas militer secara institusional ataupun individual yang pada dasarnya telah menjangkau ranah bisnis yang biasanya dilakukan oleh kalangan sipil, baik dalam bentuk kepemilikan saham, kegiatan pengamanan bisnis di lapangan dengan menjalankan tugas sebagai tenaga pengaman, pemberian surat jalan, referensi, sebagai pemungut uang keamanan, ataupun terlibat dalam kegiatan sebagai pedagang atau aktor bisnis komoditas apapun di lapangan (Nainggolan, 2007: 9).

Masih belum maksimalnya pelaksanaan reformasi TNI, khususnya yang menyangkut persoalan bisnis militer, dapat menjadi ancaman bagi pelaksanaan dan perkembangan demokrasi 
di Indonesia, sebab hal ini berpotensi terhadap gagalnya pewujudan TNI yang handal dan profesional. Oleh karena itu wajar apabila masyarakat selalu mengingatkan agar DPR bersungguhsunguh dan secara lebih serius dalam mengawasi jalannya reformasi TNI, khususnya dalam persoalan pengalihan dan penghapusan bisnis TNI.

Berdasarkan latar belakang yang telah diuraikan maka peneliti merumuskan masalah penelitian ini sebagai berikut: Bagaimana pengawasan DPR-RI dalam bisnis militer yang merupakan bagian dari reformasi Tentara Nasional Indonesia (TNI)?

\section{KERANGKA TEORETIK}

\section{Pengawasan Parlemen}

Parlemen merupakan salah satu lembaga perwakilan politik yang menjadi bagian dari suatu sistem pemerintahan disamping eksekutif dan yudikatif, yang keberadaannya jelas ditujukan untuk memberikan jaminan kepada rakyat yang diwakilinya agar suara, aspirasi, dan kepentingan mereka tetap terjaga. Keberadaan parlemen juga menjadi penting tatkala lembaga ini bertugas untuk memastikan agar kekuasaan pemerintah tidak disalahgunakan untuk kepentingan penguasa, oleh karena itu parlemen menjadi salah satu lembaga politik yang keberadaannya penting dalam penyelenggaraan demokrasi.

Dalam masa transisi demokrasi dan reformasi saat ini, keberadaan suatu lembaga negara, tidak terkecuali militer, tidak akan terlepas dari adanya pengawasan yang dilakukan oleh parlemen (DPR) selaku representasi dari warga negara Indonesia, pengawasan yang diperankan oleh DPR merupakan salah satu bagian penting dalampelaksanaan fungsibadan legislatif,khususnya di Indonesia. Sebelum mendefiniskan tentang pengawasan, bagaimana langkah atau proses pengawasan, serta keamanan dan pertahanan, sangat penting untuk mengetahui terlebih dahulu apa saja yang merupakan fungsi dan peran dari lembaga legislatif.

Mengikuti pandangan Apter (1977: 230) dan Budiardjo (2000: 182-183), fungsi dan peranan badan legislatif atau parlemen adalah untuk membuat, menentukan, dan menyetujui undang-undang sebagai sebuah kebijakan, serta mengamandemen atau mengubah undang- undang tersebut. Disamping itu parlemen juga berfungsi untuk mengontrol atau mengawasi badan eksekutif (pemerintah) yang akan melaksanakan undang-undang, dalam arti parlemen menjaga agar supaya semua tindakan eksekutif sesuai dengan kebijakan yang telah ditetapkan.

Sedangkan Joyce dalam bukunya yang berjudul Politics menjelaskan bahwa lembaga legislatif mempunyai beberapa fungsi yang melekat pada dirinya, yaitu:

1. Law making. Legislatures constitute the law-making body within a country's system of government. Thus making the law (or amanding or repealing it) is a key function which they perform.

2. Scrutiny of the executive. Legislature also scrutinize the actions of the executive branch of government.

3. Investigatory functions. The investigation of issues of public importance is an important function of many legislative bodies.

4. Supervisory functions. Legislature may concern themselves with the manner in which an institution of government or an activity that is reliant on public funds is being performed.

5. Judicial functions. Legislatures also perform judicial functions whereby members of all three branches of government may be tried and sentenced in connection with offences connected with the performance of their official duties(Joyce, 2003: 202-206).

Dalam sebuah negara demokrasi pengawasan yang efektif oleh parlemen dalam sektor pertahanan telah menjadi suatu hal yang lebih penting, hal ini untuk menjamin bahwa reaksi-reaksi yang timbul akibat perubahan konsep pertahanan dapat direncanakan dan dilaksanakan dengan penuh transparansi dan pertanggungjawaban. Tanpa itu, ada bahaya bahwa aktor pertahanan akan salah mengerti misi mereka dan bertindak seperti negara dalam negara, dengan membebani sumber-sumber daya yang dimiliki oleh negara, atau menggunakan pengaruh politik dan ekonomi yang berlebihan.

Pengawasan terhadap TNI selaku aktor pertahanan merupakan salah satu bagian yang tidak terpisahkan dari pengawasan yang efektif dan menyeluruh terhadap sistem keamanan nasional, yang dalam hal ini dikenal dengan 
sebutan "pengawasan berlapis" (multi-layered oversight). Adapun yang dimaksud dengan pengawasan belapis adalah sistem pengawasan konsentrik yang dilakukan oleh berbagai dinas atau instansi dimana secara berurutan pengawasan yang dilakukan oleh sebuah dinas menjadi cakupan pengawasan dinas berikutnya. Pengawasan berlapis dilakukan dengan menempatkan pengawasan terhadap aktor keamanan nasional di titik pusat lingkaran dengan tujuan menjamin dan meningkatkan akuntabilitas politik, hukum dan keuangan (Prihatono, dkk., 2007: 34).

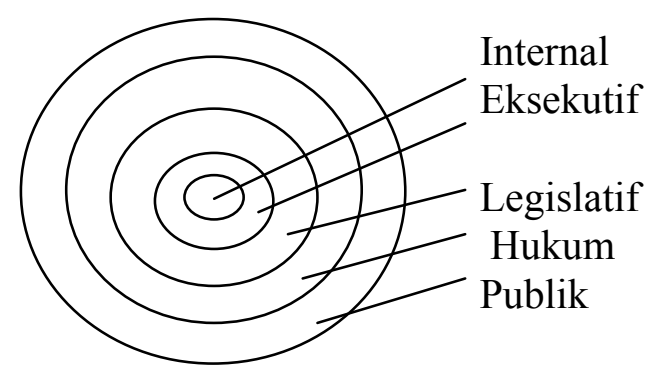

Sumber: Prihatono, dkk., 2007: 141

\section{Gambar 1. Pengawasan Berlapis}

Pengawasan terhadap Tentara Nasional IndonesiaolehDPRmasukkedalampengawasan berlapis di lapisan ketiga. Dilapisan ketiga, pengawasan terhadap aktor keamanan nasional didasari pada prinsip bahwa pelaksanaan tugas atau fungsi keamanan nasional harus merupakan penjabaran dari mandat yang diberikan dalam undang-undang dan diawasi pelaksanaannya berdasarkan undang-undang tersebut. DPR secara khusus berkepentingan dengan tetap tegaknya prinsip rule of law dalam pelaksanaan kebijakan dan strategi keamanan nasional dan sekaligus memiliki tanggung jawab timbal balik yang berkaitan dengan masalah keamanan nasional.

Pelaksanaan fungsi pengawasan atau kontrol yang dilakukan oleh parlemen dalam mengawasi jalannya reformasi TNI tidak akan terlepas dari suatu bentuk kontrol sipil dalam hubungannya dengan militer. Huntington (2003: 87) dalam bukunya Prajurit dan Negara: Teori dan Politik Hubungan Militer-Sipil, mengungkapkan bahwa masalah mendasar dalam mendefinisikan kontrol sipil adalah bagaimana kekuasaan militer dapat diminimalkan.

Berkaitan dengan kualifikasinya sebagai wakil rakyat sesungguhnya pengawasan yang dilakukan oleh badan perwakilan rakyat pertama kali berkenaan dengan keputusan yang telah dikeluarkannya dalam bentuk undang- undang. Eksekutif dan yudikatif yang bertindak sebagai pelaksana perlu dinilai apakah cukup tepat melaksanakan keputusan tersebut. Kedua, pengawasan itu merupakan konsekuensi dari kekuasaan rakyatyang dioperasikannya. Sebagai pemegang mandat kekuasaan badan perwakilan bertanggung jawab atas pemanfaatan mandat tersebut kepada pemberinya (Sanit, 1985: 5152).

Pentingnya pelaksanaan fungsi pengawasan oleh parlemen atau lembaga legislatif juga diutarakan oleh Joyce dalam bukunya yang berjudul Politics, dimana Joyce berpendapat bahwa:

"This function (which in America is termed oversight) is concerned with monitoring the bureaucracy and its administration of policy. This entails ensuring that an agency is meeting the goals specified for it, that the public money provided for it is being spent for the purposes which it was intended or that an operation is conducted in accordance with any restrictions which were initially placed upon it by legislature" (Joyce, 2003: 205).

Joyce (2003: 207) mengemukakan bahwa dalam melakukan fungsi pengawasan ada beberapa operasi legislatif atau sejumlah mekanisme pengawasan yang dapat dipergunakan oleh lembaga ini yaitu: perdebatan (debate); komisi (committees); dan pertanyaan-pertanyaan (questions).

Guna mengefektifkan fungsi pengawasan politik yang dimiliki oleh DPR khususnya dalam mengawasi jalannya pelaksanaan reformasi TNI, maka parlemen dapat menggunakan sejum-lah syarat-syarat tertentu untuk melakukan pengawasan demokratis yang efektif dalam pelaksanaan reformasi TNI. Beberapa syaratsyarat tertentu tersebut adalah:

1. Clearly defined constitutional and legal powers

2. Customary practices

3. Resources and expertise

4. Political will.

(IPU dan DCAF, 2003: 75)

\section{Keamanan Nasional dan Pertahanan}

Berbicara tentang pengawasan yang dilakukan oleh Dewan Perwakilan Rakyat Republik Indonesia dalam reformasi Tentara Nasional 
Indonesia sebagai aktor di bidang pertahanan, maka perlu didefinisikan terlebih dahulu pengertian tentang pertahanan yang didalamnya mencakup keseluruhan sistem, aktor yang berperan dalam menjaga pertahanan. Pertahanan itu sendiri pada dasarnya merupakan bagian yang tidak terpisahkan dari keamanan nasional. Pertahanan dan keamanan nasional (National Security and Defence) dapat diartikan sebagai pertahanan keamanan negara yang merupakan salah satu fungsi pemerintahan negara, yang mencakup upaya dalam bidang pertahanan yang ditujukan terhadap segala bentuk ancaman dari luar negeri (Lemhannas, 1994: 167).

Sebelum memahami apa itu pertahanan, maka terlebih dahulu akan dipaparkan konsep tentang keamanan nasional yang merupakan konsep umum dari pertahanan. Keamanan nasional (National Security) merupakan sebuah permasalahan yang sangat kompleks. Istilah "nasional" (national) mengandung makna yang luas, tidak hanya mencakup negara sebagai subyek maupun obyek tunggal, tetapi juga melingkupi berbagai entitas yang ada di dalamnya. Secara etimologis, konsep "keamanan" (security) berasal dari bahasa latin "securus" (se + cura), yang memiliki makna terbebas dari bahaya, terbebas dari ketakutan (free from danger, free from fear). Kata ini juga bisa bermakna dari gabungan kata se yang berarti tanpa (without) dan curus yang berarti kesulitan (uneasiness). Apabila digabungkan, kata tersebut akan bermakna "kebebasan dari kesulitan, atau sebuah situasi damai tanpa bahaya atau ancaman" (liberation from uneasiness or a peaceful situation without any risk or threat) (Prihatono, dkk., 2007: 1).

Menurut La Ode "Konsep National Security lebih memuat makna yang mencakup penanggulangan atas ancaman bagi kelangsungan hidup negara, baik yang datang dari dalam maupun dari luar" (La Ode, 2006: 46). Apa yang dikemukakan oleh La Ode tentang adanya ancaman dari dalam dan dari luar akan membantu kita untuk membagi keamanan nasional ke dalam dua makna, yaitu makna antara keamanan (untuk ancaman dari dalam) dan pertahanan (untuk ancaman dari luar).

Sedangkan pengertian keamanan nasional menurutMahfudz, terfokus pada dua variabel, yaitu: pertama, penanggulangan ancaman kehidupan langsung hidup negara yang datang dari dalam negeri (keamanan); kedua, penanggulangan ancaman kehidupan langsung hidup negara yang datang dari luar negeri (pertahanan) ( $\mathrm{La}$ Ode, 2006: 47). Adapun Laksada TNI (Purn.) Wahyono SK mengatakan bahwa keamanan nasional adalah fungsi dan sekaligus kondisi tegaknya kedaulatan dan hukum negara, terjaminnya kelangsungan hidup bangsa dan negara serta perikehidupan rakyat, masyarakat dan pemerintah dalam skala nasional dan internasional (La Ode, 2006: 49).

Walaupun konsep keamanan nasional (National Security) dapat dibedakan antara han (pertahanan) dan kam (keamanan), tetapi dalam implementasi terbuka kemungkinan terjadinyatumpang tindih(overlap) penanganan atau kekosongan penanganan antara TNI dan Polri. Menurut Mahfudz sebagaimana dikutip oleh La Ode (2006: 46) terjadinya tumpang tindih penanganan antara TNI dan Polri disebabkan masing-masing institusi tersebut merasa bertanggung jawab atau sebaliknya malah tidak bertanggung jawab.

Adapun pertahanan itu sendiri, sebagai bagian dari keamanan nasional, sebagaimana dikemukakan oleh Andi Widjajanto adalah: "pertahanan negara adalah segala usaha untuk mempertahankan kedaulatan negara, keutuhan wilayah negara, dan keselamatan segenap bangsa dari ancaman dan gangguan terhadap keutuhan bangsa dan negara" (Bakrie, 2007: 49).

Pengertian yang tidak jauh berbeda tentang pertahanan juga dikemukakan oleh Suryohadiprojo (2005: 6), dimana pertahanan negara adalah sistem keamanan terhadap kegiatan yang bersumber kekuatan luar negeri dan umumnya bersifat serangan dengan kekuatan militer oleh negara lain.

Berdasarkan pada peraturan perundangundangan, yaitu pada Pasal 1, UU No. 34 Tahun 2004 tentang Tentara Nasional Indonesia, yang dimaksudkan dengan pertahanan negara adalah:

"Pertahahanan negara adalah segala usaha untuk menegakkan kedaulatan negara, mempertahankan keutuhan wilayah Negara Kesatuan RepublikIndonesia, danmelindungi keselamatan segenap bangsa dari ancaman dan gangguan terhadap keutuhan bangsa dan negara, disusun dengan memperhatikan kondisi geografis Indonesia sebagai negara kepulauan." 


\section{METODE PENELITIAN}

Penelitian ini dilakukan melalui teknik observasidanwawancara. Datayang dikumpulan terdiri dari data primer, yaitu dari informan dan observasi, serta data sekunder di lapangan. Untuk itu desain penelitian ini menggunakan metode kualitatif. Metode penelitian ini dipilih dan dianggap tepat karena metode kualitatif relavan dan cocok dengan masalah penelitian yang diajukan melalui interpretasi proses dan makna.

Sumber data dalam penelitian yang dijalankan ini dibagi kedalam beberapa kelompok, yaitu:

1. Sumber data primer, yaitu merupakan data yang diperoleh langsung, berupa hasil wawancara dengan beberapa informan dan juga observasi.

2. Sumber data sekunder, yaitu data yang diperoleh dari:

a) Perpustakaan, sebagai sumber dalam bentuk buku-buku, karya tulis, laporan koran, dan buletin yang berkaitan dengan penelitian yang sedang peneliti jalani.

b) Dokumen atau arsip yang berupa bahanbahan tertulis, seperti dokumen pribadi, dan dokumen resmi.

Adapun teknik pengambilan informasi dari informan yang digunakan dalam penelitian ini adalah dengan menggunakan purposive sampling, yaitu jenis penentuan informan yang pemilihannya didasarkan atas kriteria tujuan dan manfaatnya.

Adapun alat bantu yang digunakan dalam penelitian ini berupa daftar wawancara sebagai uraian lebih lanjut dari pertanyaan penelitian, pedoman observasi, dan dokumentasi. Teknik ini dipilih untuk memberi kemudahan dalam kegiatan penelitian tidak dimaksudkan untuk membatasi tingkat fleksibilitas peneliti sebagai instrumen di lapangan.

Wawancara dilakukan terhadap anggota Komisi I DPR-RI; mitra kerja Komisi I DPR - RI: Kemeterian Pertahanan, Mabes TNI yang dipimpin oleh Panglima TNI; Akademisi, LSM di bidang Pertahanan, dan Pengamat Militer; Ketua Tim Nasional Pengalihan Aktivitas Bisnis TNI. Observasi dilakukan terhadap pembahasan atau diskusi tentang bisnis militer di DPR, notulensi rapat, pedoman umum, hasil studi dari berbagai litelatur dan penelitian-penelitian terdahulu yang relevan.

Lebih lanjut, proses pengumpulan data pada penelitian ini disesuaikan dengan jenis penelitian. Data yang dihimpun dalam penelitian ini, yaitu berupa kata-kata, tindakan, dokumen, situasi, dan peristiwa yang dapat diobservasi. Sumber data yang dimaksud adalah kata-kata diperoleh secara langsung atau tidak langsung melalui observasi dan wawancara dan dokumen berupa catatan kegiatan yang tersimpan dalam dokumentasi.

Pengujian keabsahan data dalam penelitian ini didasarkan atas kriteria tertentu yaitu derajat kepercayaan dan kebenaran data (credibility) yang diperoleh dari informan-informan yang terlibat dalam pengawasan atas bisnis militer, kebenaran (correctness) suatu deskripsi, simpulan, dan penjelasan (explanation) yang dapat diketahui dari kesesuaian dengan peraturan perundangan serta naskah/dokumen penting lainnya.

\section{PEMBAHASAN}

Aktivitas bisnis yang dilakukan oleh militer di Indonesia merupakan kegiatan yang sudah berlangsung sejak masa revolusi kemerdekaan, pada awalnya aktivitas ini bertujuan untuk memenuhi kebutuhan dan anggaran unit-unit militer dalam rangka melakukan perjuangan mempertahankan kemerdekaan. Seiring dengan perkembangan zaman, aktivitas bisnis militer kemudian berevolusi menjadi aktivitas bisnis berskala besar yang tidak hanya bertujuan untuk memenuhi kebutuhan dan anggaran militer semata, militer pada kenyataannya telah berhasil mengembangkan bisnisnya dan memperoleh keuntungan dari hasil usahanya dengan memanfaatkan sejumlah peluang dari berbagai peristiwa yang terjadi di tanah air.

\section{Periode Revolusi Emerdekaan (1945-1949)}

Pemenuhan anggaran sendiri oleh militer merupakan sebuah praktek yang sudah muncul sejak masa-masa revolusi kemerdekaan Indonesia, sebagian dari fenomena ini disebabkan oleh konstruksi sejarah terbentuknya Tentara Nasional Indonesia yang berasal dari perpaduan unsur unit-unit militer seperti Koninklijk Nederlands Indisch Leger (KNIL), Pembela Tanah Air (PETA) serta unsur-unsur pasukan gerilya masyarakat yang berada di tingkat daerah. 
Karena sejarah pembentukannya tersebut maka berdirinya militer di Indonesia adalah didasarkan pada prinsip unit-unit daerah atau teritorial semi otonom yang masing-masing memiliki tanggung jawab untuk memenuhi kebutuhan dana serta logistiknya masing-masing, pemenuhan kebutuhan dana serta logistik militer secara mandiri pada saat itu dilakukan untuk membayar dan membiayai tentara dalam rangka melawan kekuasaan kolonial dan mempertahankan kemerdekaan.

\section{Era Orde Lama (1950-1965)}

Perjuangan untuk memperoleh dan mempertahankan kemerdekaan berakhir pada saat pemerintah kerajaan Belanda dan pemerintah revolusi Indonesia, yang dipimpin Soekarno, melakukan negosiasi penyerahan kedaulatan pada tanggal 27 Desember 1949. Pasca penyerahan kedaulatan dari Pemerintah Kerajaan Belanda ke tangan Pemerintah Indonesia, muncul beberapa perubahan yang cukup signifikan dalam bidang sosial, politik dan ekonomi di Indonesia, perubahan ini setidaknya juga mempunyai dampak terhadap perubahan pola aktivitas bisnis TNI dari yang sekedar memenuhi kebutuhan logistik, anggaran dan prajurit menjadi aktivitas bisnis yang dapat mendatangkan keuntungan.

Walaupun militer Indonesia diketahui telah memainkan aktivitas bisnisnya sejak awal masa kemerdekaan, namun baru pada tahun 1957 peranan ini dilembagakan seiring dengan diterapkannya status negara dalam keadaan darurat ketika Indonesia berkonfrontasi dengan Belanda dalam persoalan status Irian Barat. Demontrasi anti Belanda yang terjadi pada saat itu telah membuka jalan bagi militer untuk mengambil alih keadaan termasuk mengambil alih kontrol seluruh perusahaan milik Belanda, dimana hal ini juga didukung oleh kebijakan pemerintah yang menasionalisasi seluruh perusahaan asing yang ada di Indonesia.

\section{Era Orde Baru (1968-1998)}

Seiring dengan semakin berkembangnya aktivitas bisnis militer pada era orde lama, aktivitas bisnis militer pada era orde baru juga semakin mudah berkembang seiring dengan terbukanya ruang bagi peran politik militer melalui doktrin dwifungsi ABRI, dapat dikatakan di dalam tubuh TNI (dahulu ABRI) kemudian terhimpun kesatuan kekuatan militer- politik-ekonomi. Latar belakang sejarah pada masa pemerintahan Soekarno yang kemudian didukung dengan kebijakan pada masa pemerintahan Soeharto telah membuat militer Indonesia semakin menikmati aktivitasnya dalam dunia ekonomi dan bisnis, hal inilah yang kemudian terlihat bahwa TNI memiliki banyak yayasan dan sejumlah koperasi atau unit-unit bisnis lain sehingga berakibat pada lemahnya profesionalisme TNI dalam bidang pertahanan.

\section{Bisnisi Militer Di Era Reformasi}

Seiring dengan bergulirnya era reformasi pada tahun 1998, TNI dituntut untuk mau melaksanakan reformasi internal dimana sebagai bagian dari reformasi internal tersebut TNI harus mau dan mampu melepaskan berbagai fungsi politik dan ekonominya, keinginan masyarakat agar TNI melakukan reformasi di dalam tubuhnya didasari atas adanya suatu upaya untuk menjadikan TNI sebagai aktor serta alat pertahanan negara yang handal dan profesional. Dampak dari ketidak profesionalan TNI, terutama terkait dengan aktivitas bisnis yang dijalankannya, berakibat pada lemahnya kekuatan pemerintah sipil yang berdaulat dalam menetapkan tujuan nasional, disamping juga mampu mengalihkan perhatian TNI dari tugas utama mereka sebagai aktor utama pertahanan negara yang seharusnya siap menjaga pertahanan negara dari segala ancaman.

Dalam kaitannya dengan upaya menghapuskan aktivitas bisnis yang dilakukan TNI, maka kemudian lahir undang-undang TNI yang di dalamnya mengatur tentang larangan berbisnis bagi anggota TNI dan adanya upaya pengambilalihan aktivitas bisnis militer oleh pemerintah. Dimasukkannya ketentuan larangan berbisnis bagi TNI dan juga adanya kewajiban bagi pemerintah untuk mengambil alih aktivitas bisnis TNI dalam kurun waktu 5 tahun, bertujuan agar TNI menjadi aktor yang handal dan profesional.

Dalam rangka mendukung proses penghapusan dan pengambilalihan aktivitas bisnis militer diperlukan adanya pengawasan berlapis (multi-layered oversight), dalam konsep pengawasan yang bersifat multi-layered maka pengawasan DPRRI sebagai lembaga yang merepresentasikan kepentingan masyarakat dalam reformasi TNI sangat penting untuk dilaksanakan. 
Sejalan dengan adanya upaya untuk menjadikan TNI sebagai aktor pertahanan yang handal dan profesional serta untuk mengambil alih seluruh aktivitas bisnis militer seperti yang telah diamanahkan oleh UU No. 34 Tahun 2004, maka DPR mempunyai tanggung jawab untuk melakukan pengawasan terhadap pelaksanaan kebijakan pengambilalihan aktivitas bisnis TNI oleh pemerintah. Bentuk pengawasan atas kebijakan pengalihan aktivitas bisnis TNI menurut anggota Komisi I DPR Periode 20042009 dari F-PKS, Suryama, salah satunya dilakukan melalui mekanisme tanya jawab dan perdebatan dalam rapat kerja antara Komisi I DPR dengan Menteri Pertahanan dan Panglima TNI, sedangkan pada tataran teknis operasional dilakukan melalui Rapat Dengar Pendapat (RDP) dengan Kepala Staf masing-masing angkatan beserta jajaran mereka.

Aktivitas pengawasan yang dilakukan oleh DPR terhadap proses pengambilalihan bisnis TNI juga merupakan salah satu bentuk tangung jawab yang diberikan oleh para wakil rakyat kepada rakyat, disamping itu pengawasan juga bertujuan agar reformasi TNI terus berjalan dan kepentingan rakyat dapat terlindungi. Terdapat sebuah alasan yang dikemukakan oleh seorang pemerhati pertahanan bahwa aktivitas bisnis yang dilakukan oleh TNI harus dihapuskan karena selama ini aktivitas bisnis TNI juga memberikan kontribusi negatif terhadap perlindungan hak asasi manusia. ${ }^{1}$

Berdasarkan pada teori mekanisme pengawasan parlemen yang dikemukakan oleh Joyce, maka terdapat 3 aspek dalam suatu mekanisme pengawasan, yaitu: debat (debate); komisi-komisi (committees); dan pertanyaanpertanyaan (questions).

\section{Perdebatan Tentang Bisnis Militer di DPR-RI}

Perdebatan-perdebatan di DPR merupakan salah satu bagian yang tidak dapat dilepaskan dari mekanisme pengawasan yang dilakukan oleh parlemen, di setiap negara yang menganut nilainilai demokrasi, perdebatan di dalam parlemen merupakan suatu hal yang dijamin kebebasannya. Bagi anggota parlemen debat merupakan salah satu bagian dari mekanisme pengawasan dari beberapa bagian mekanisme pengawasan yang cukup penting dan secara politik berguna bagi

${ }^{1}$ Lihat juga makalah Adnan Topan Husodo, Bisnis Militer: Agenda Reformasi yang Tak Kunjung Usai, http://idsps.org/publikasi-idsps/makalah/adnan-t/ [19/12/2008] para anggota dewan, di dalam perdebatan setiap anggota legislatif dapat menuangkan berbagai sikap dan pandangan politik mereka terkait dengan fungsi pengawasan yang sedang mereka jalankan.

Pelaksanaan fungsi pengawasan oleh DPR dalam persoalan bisnis TNI, seringkali diwarnai oleh adanya suasana perdebatan-perdebatan dalam setiap rapat kerja atau rapat dengar pendapat (RDP) dengan pemerintah, yang diwakili oleh menteri pertahanan dan/atau Panglima TNI. Sama seperti dengan negara-negara demokrasi lainnya, dalam nuansa per-debatan setiap anggota Komisi I DPR-RI dapat menikmati kebebasan dalam berbicara, hal ini merupakan satu dari sejumlah hak istimewa yang dimiliki oleh parlemen. Hal ini juga mempunyai arti bahwa anggota parlemen secara efektif dapat mengatakan apa yang mereka inginkan, namun tetap tunduk kepada aturan-aturan pimpinan sidang atau tata tertib persidangan.

Di dalam nuansa perdebatan setiap anggota Komisi I DPR-RI dapat melontarkan ungkapanungkapan dimana mereka meletakkan jauh kedepan pandangan dan sikap mereka serta mendengarkan pendapat rekan mereka sesama anggota legislatif dalam persoalan yang sama, yaitu persoalan penghapusan dan pengalihan aktivitas bisnis yang dijalankan oleh TNI dan pengambilalihan bisnis TNI oleh pemerintah. Berbagai pendapat atau pandangan yang muncul dalam suasana perdebatan pun menjadi suatu nilai tersendiri bagi jalannya demokrasi di Indonesia hal ini tercermin dari pandangan anggota Komisi I DPR Periode 2004-2009 dari Partai Golkar, Chrisnandi, bahwa perdebatan di dalam parlemen adalah suatu hal yang wajar dalam negara demokrasi. Pernyataan yang dikeluarkan oleh Chrisnandi tentunya juga harus disesuaikan dengan konteks permasalahan yang dibahas dan tata tertib sidang yang berlaku sehingga suatu kondisi yang demokratis benarbenar akan tercermin dalam setiap pengawasan yang dilakukan DPR.

Sebagai sebuah lembaga legislatif, setiap anggota Komisi I DPR-RI memiliki sumber data dan fakta yang mereka peroleh dari berbagai sumber atau kalangan termasuk dari berbagai Lembaga Swadaya Masyarakat (LSM) yang bergerak di bidang pertahanan, pengamat militer, akademisi, dan juga media walaupun terkadang data dan fakta yang diperoleh oleh para anggota 
DPR tidak terlalu cukup. Berbagai data dan fakta yang dimiliki oleh anggota Komisi I merupakan sebuah acuan yang dapat digunakan di dalam melakukan perdebatan setiap berlangsungnya rapat antara DPR dengan pemerintah, sebagaimana hal ini diungkapkan oleh salah satu anggota Komisi I DPR Periode 2004-2009 dari F-PKS, Suryama.

Peneliti menilai bahwa sumber-sumber data dan informasi yang tepat dan akurat merupakan suatu hal yang penting dalam melakukan sebuah perdebatan dalam hal pelaksanaan fungsi pengawasan oleh DPR, sebab tanpa adanya acuan data dan fakta maka perdebatan yang terjadi hanya akan menjadi sebuah debat kusir yang tentunya tidak akan menghasilkan sesuatu yang berguna dan cenderung mengarah pada hal-hal yang terlalu subjektif, yaitu cenderung memvonis dan memposisikan militer dalam keadaan sebagai terdakwa. Sebetulnya dalam sebuah negara demokrasi yang lebih mengedapankan adanya pengawasan parlemen yang bersifat objektif terhadap kalangan militer, maka setiap perdebatan harus didasari atas sebuah fakta dan data yang konkrit dan bukan berdasarkan atas tuduhan ataupun sanggahan tanpa bukti, dimana hal ini juga untuk menghindari atau meminimalisir terjadinya konflik dua belah pihak.

Selama ini sebagian kalangan masyarakat menilai bahwa perdebatan di dalam DPR hanyalah debat "kusir" yang mencerminkan "arogansi DPR" sehingga dianggap kurang bermanfaat, pandangan ini merupakan suatu hal yang sepenuhya tidaklah benar. Di dalam setiap negara demokrasi perdebatan antara legislatif dengan eksekutif merupakan suatu hal yang wajar selama pelaksanaan debat sesuai dengan aturan atau tata tertib sidang yang berlaku serta di dukung oleh data dan fakta sebagaimana telah diulas di atas, disamping itu dengan perdebatan yang terarah atau sesuai dengan konteks pembahasan maka akan memberikan nilai positif bagi jalannya pengawasan itu sendiri sehingga anggota DPR pun akan semakin dapat menggali informasi dan memberikan solusi, contohnya seperti solusi untuk meningkatkan kesejahteraan para prajurit sebagai bentuk kompensasi dilarangnya TNI melakukan aktivitas bisnis.

Terkait pentingnya perdebatan dalam sebuah mekanisme pengawasan, para pengamat pertahanan menekankan pentingnya perdebatan-perdebatan yang lebih substantif yang harus dilakukan oleh para anggota Komisi I DPR-RI dalam setiap rapat dengan menteri pertahanan, Panglima TNI, kepala staf tiga angkatan dan Timnas. Dalam persoalan ini seorang peneliti bisnis militer, Primodhawardani, mengungkapkan bahwa perdebatan di dalam DPR masih selalu mengaitkan antara kesejahteraan prajurit anggaran pertahanan dan bisnis padahal ketiganya adalah hal yang berbeda, pendapat ini juga tidak jauh berbeda dengan yang telah diungkapkan oleh beberapa informan seperti: Sukadis, Anggoro dan Prihatono.

Selaku pengamat dan peneliti bisnis militer, Pramodhawardani, mengungkapkan bahwa perdebatan tentang bisnis militer oleh anggota Komisi I DPR, seharusnya didasari pada pemikiran bahwa aktivitas bisnis TNI menciptakan distorsi dalam ekonomi nasional dan menghambat pertumbuhannya. Disamping itu dalam bisnis segala aktivitas itu harus adil (fair) masuknya TNI dalam aktivitas bisnis mengakibatkan bisnis menjadi tidak adil sebab satu pihak memegang senjata sementara dipihak lain tidak. Dengan kata lain dari apa yang dikemukakan oleh informan, bahwa perdebatan yang dilakukan oleh anggota Komisi I DPR harus substantif, dan tidak berputar hanya pada persoalan kesejahteraan prajurit - anggaran pertahanan - dan bisnis. Sehingga mau tidak mau, tidak ada alasan bagi TNI untuk tidak melepaskan bisnis yang dikelolanya.

\section{Peranan Komisi di DPR Dalam Peng- awasan Bisnis Militer}

Dalam mekanisme pengawasan, keberadaan komite atau komisi di parlemen sangat dibutuhkan. Pada umumnya seluruh informan pun menganggap pentingnya keberadaan komisi di dalam DPR yang didukung dan diperkuat dengan sejumlah fungs-fungsi salah satunya fungsi pengawasan, tanpa keberadaan komisi yang secara khusus menangani bidang pertahanan maka akan sulit bagi DPR untuk menjalankan tugas dan kewajiban mereka secara efektif dan efisien dalam melakukan fungsi pengawasan terhadap reformasi bisnis militer.

Seperti telah dijelaskan dalam pembahasan terdahulu bahwa pengawasan terhadap reformasi TNI oleh DPR dilaksanakan oleh Komisi I yang salah satu ruang lingkup tugasnya berada di 
ranah pertahanan, berbicara tentang pengawasan yang dilakukan oleh Komisi IDPR-RI dalam hal reformasi bisnis militer, maka di dalam Komisi I terdapat Kelompok Kerja (Pokja) pertahanan yang bertugas menelaah dan mengawasi jalannya pengambilalihan aktivitas bisnis TNI. Akan tetapi, pada tahun 2008 intensitas pengawasan bisnis militer yang dilakukan oleh Komisi I DPR-RI menurun, beberapa kalangan LSM Pertahanan seperti Sukadis menilai bahwa hal tersebut lebih dikarenakan masih belum adanya orientasi atau visi yang jelas dari anggota Komisi I DPR-RI itu sendiri dan pengawasan yang dilakukan juga masih bersifat reaktif atau tidak bersifat kontinu.

Peneliti juga mengamati bahwa pengawasan Komisi I di semua sektor tidak selamanya berjalan dengan seimbang, hal ini dapat disebabkan oleh beberapa faktor diantaranya pengawasan yang dilakukan oleh anggota Komisi I masih berorientasi jangka pendek dan disesuaikan dengan kepentingan para anggota dewan. Dika-renakan pengawasan yang dilakukan oleh Komisi I pun masih banyak yang bersifat reaktif, maka suatu isu akan lebih mendapat perhatian anggota DPR jika sudah menjadi besar dan mendapat perhatian banyak masyarakat. Hal ini pun akhirnya memunculkan dua spekulasi pendapat, yang pertama menilai bahwa kinerja anggota Komisi I DPR dalam hal pengawasan, khususnya bisnis militer masih lemah, dan yang kedua bahwa anggota DPR hanya memperhatikan suatu masalah untuk mendapatkan perhatian dari rakyat.

Beberapa kalangan berpendapat, seperti dari LSM pertahanan, akademisi, tokoh TNI reformis dan juga pengamat militer bahwa persoalan bisnis militer merupakan sebuah persoalan yang serius, oleh karena itu dalam menyelesaikan persoalan ini peran pengawasan DPR mutlak diperlukan dan DPR harus memanfaatkan unit-unit kerja yang ada di dalamnya untuk mengawasi jalannya penghapusan dan pengambilalihan bisnis TNI. Peranan Pokja pertahanan di dalam Komisi I mempunyai peran strategis yang dapat membantu penyelenggaraan tugas Komisi I di bidang pertahanan, oleh karenanya keberadaan unit tersebut harus dimaksimalkan khususnya dalam hal melakukan pengawasan terhadap proses penghapusan dan pengalihan aktivitas bisnis TNI.

Persoalan bisnis TNI bukanlah persoalan kecil sebab setiap aktivitas bisnis yang dilakukan TNI juga mempunyai dampak negatif terhadap upaya penegakkan demokrasi dan HAM serta juga dalam bidang ekonomi, maka dari itu tugas Komisi I, khususnya Pokja pertahanan, adalah mengawasi segala hal yang memiliki keterkaitan dengan upaya mereformasi TNI tanpa terkecuali. Tentunya jika kinerja Komisi I dalam melakukan pengawasan terhadap bisnis militer tidak segera diperbaiki atau pengawasan yang dilakukan tidak segera dilaksanakan dengan sungguh-sungguh, bukan tidak mungkin pelaksanaan penghapusan bisnis TNI yang seharusnya selesai pada tahun 2009 menjadi tidak akan selesai dan ini secara langsung maupun tidak langsung juga akan mengancam upaya-upaya penegakkan demokrasi dan supremasi sipil.

\section{Jalannya Proses Bertanya Di DPR-RI}

Pertanyaan merupakan salah satu bagian yang tidak dapat dilepaskan dari mekanisme pengawasan yang dijalankan oleh lembaga legislatif, di dalam setiap negara yang menganut asas dan prinsip demokrasi pertanyaan sebagai bagian dari mekanisme pengawasan juga merupakan hak dari setiap anggota parlemen. Berdasarkan hasil penilitian dilapangan, diketahui bahwa anggota Komisi I DPR-RI menggunakan dua cara dalam bertanya yaitu pertanyaan yang diajukan secara lisan dan tulisan.

Walaupun banyak anggota DPR menggunakan hak untuk bertanya sebagai salah satu alat dalam menjalankan fungsi pengawasan, tetapi beberapa informan dari kalangan pemerhati pertahanan, akademisi dan juga dari kalangan DPR sendiri menganggap bahwa pertanyaan yang diajukan oleh anggota Komisi I DPR dalam persoalan bisnis militer pun masih dirasakan kurang dan tidak terlalu substantif. Beberapa permasalahan seputar pertanyaan-pertanyaan yang tidak terlalu substantif pada dasarnya disebabkan oleh persiapan yang kurang cermat, sebab mustahil untuk melakukan improvisasi kalau pertanyaan yang diajukan berhubungan dengan masalah-masalah pertahanan, terutama yang bersifat teknis.

Hal ini tentunya sangat disayangkan, sebab menurut Ameller sebagaimana dikutip oleh IPU dan DCAF (2003: 81) pertanyaan dapat bermanfaat dalam mengeruk informasi konkret dari pemerintah, meminta intervensinya, dan bilamana perlu, mengungkapkan penyalahgunaan dan mengusahakan perbaikan, disamping itu pertanyaan juga dapat digunakan untuk men- 
dapatkan fakta-fakta rinci yang akan membantu para anggota memahami masalah-masalah yang kompleks.

Terkait dengan beberapa pertanyaan yang seringkalidilontarkanolehanggotaKomisiIDPR kepada mitra kerja dari pemerintah, ada suatu kecendrungan dimana anggota Komisi I DPR kurang efektif dalam melontarkan pertanyaanpertanyaan. Ketidakefektifan itu terlihat dari pertanyaan tentang penghapusan bisnis TNI yang selalu dikaitkan dengan minimnya jumlah anggaran yang diberikan negara bagi sektor pertahanan. Sebagai contohnya adalah:

"Anggaran yang disediakan oleh negara melalui APBN untuk petahanan negara terbatas jumlahnya untuk memenuhi kebutuhan TNI AD, sementara itu, sesuai dengan ketentuan Pasal 76 UU No. 34 Tahun 2004 tentang TNI, pemerintah harus mengambil alih seluruh aktivitas bisnis yang dimiliki dan dikelola oleh TNI.

a. Bagaimana rencana strategis TNI AD, khususnya untuk lima tahun kedepan menghadapi keadaan trsebut?

b. Bagaimana pimpinan TNI AD mengantisipasi perubahan tersebut dikaitkan dengan kesejahteraan prajurit?"

(Sumber: Komisi I DPR, RDP dengan KASAD pada tahun 2005)

Kenyataan ini bagi sebagian besar informan membuat TNI akan selalu berdalih bahwa bisnis TNI baru akan benar-benar berhenti apabila negara telah memenuhi kebutuhan minimum anggaran pertahanan, yang salah satu alasannya digunakan untuk pemenuhan kebutuhan dan kesejahteraan para prajurit TNI, walaupun pada kenyataannya hal ini tidak selamanya selalu berkaitan, sebab pada faktanya bisnis TNI yang dijalankan selama ini lebih banyak menguntungkan para petinggi TNI dibandingkan untuk kesejahteraan prajurit itu sendiri.

Seperti telah dibahas dalam paragraf sebelumnya bahwa pertanyaan sebagai bagian dari mekanisme pengawasan akan dapat efektif apabila memenuhi beberapa persyaratan seperti: perlu persiapan yang cermat(through preparation), bahasa yang lugas(unequivocal language), dan waktu (timing) yang tepat, sedangkan realita yang terjadi selama ini menunjukkan bahwa beberapa pertanyaan yang disampaikan oleh anggota Komisi I DPRRI kepada Menteri Pertahanan dan petinggi TNI cenderung diajukan tanpa persiapan yang cermat, tanpa bahasa yang lugas dan waktu yang kurang tepat.

\section{SIMPULAN}

Berdasarkan hasil penelitian dan pembahasan yang telah diuraikan sebelumnya, maka dengan ini peneliti membuat suatu simpulan terhadap penelitian yang telah dijalankan adalah sebagai berikut:

1. Bisnis militer di Indonesia merupakan kegiatan yang sudah berlangsung sejak masa revolusi kemerdekaan, aktivitas ini tumbuh dan berkembang seiring dengan berjalannya waktu. Dari berbagai aktivitas bisnis yang telah dijalankan, TNI dapat memenuhi berbagai kebutuhannya secara mandiri, aktivitas bisnis TNI dilakukan melalui berbagai unit usaha, baik yang bersifat formal dan informal maupun legal dan illegal, akibat dari aktivitas bisnis yang dijalankannya maka TNI cenderung tidak bersikap profesional.

2. Sebagai lembaga yang mewakili kepentingan rakyat, DPR mempunyai hak dan kewajiban untuk mengawasi proses pengalihan dan penghapusan aktivitas bisnis militer. Pengawasan DPR dalam bisnis militer mempunyai peranan penting dalam upaya menciptakan TNI yang handal dan profesional, dan untuk mencapai tujuan itu pengawasan dilakukan melalui sejumlah mekanisme seperti perdebatan, adanya komisi, dan pertanyaan.

3. Bahwa masih terdapat kelemahan dari mekanisme pengawasan yang dijalankan oleh DPR, seperti masih belum substantifnya perdebatan-perdebatan di dalam rapat yang selalu mengaitkan antara kesejahteraan prajurit anggaran pertahanan dan bisnis, sehingga apabila kesejahteraan pajurit belum terpenuhi maka TNI dapat terus membenarkan aktivitas bisnis yang dijalankannya selama ini. Disamping itu pertanyaan yang diajukan oleh anggota DPR dalam membahas persoalan bisnis militer tidak semunya bersifat substantif sehingga mempengaruhi kulitas pertanyaan yang diajukan. Walaupun masih terdapat beberapa kelemahan dari mekanisme pengawasan yang dijalankan oleh DPR, 
tetapi keberadaan Komisi I sebagai komisi yang salah tugasnya bergerak di sektor pertahanan cukup berperan dalam membantu pelaksanaan mekanisme pengawasan, hanya saja pengawasan Komisi I dalam bisnis militer masih bersifat reaktif dan kontinuitas pembahasan bisnis militer masih lemah.

\section{DAFTAR PUSTAKA}

Anggoro, Kusnanto, dan A.A. Banyu Perwita (eds.). 2006. Rekam Jejak Proses 'SSR' Indonesia 2000-2005. Jakarta: ProPatria Institute.

Anwar, Dewi Fortuna. 2004. "Sasaran Sishankamneg 5-10 tahun Mendatang" dalam Indria Samego (ed.). Sistem Pertahanan-Keamanan Negara: Analisis Potensi dan Problem. Jakarta: The Habibie Center.

Asshiddiqie, Jimly. 2006. Perkembangan dan Konsolidasi Lembaga Negara Pasca Reformasi. Jakarta: Konstitusi Press.

Bakrie, Connie R. 2007. Pertahanan Negara dan Postur TNI Ideal. Jakarta: Yayasan Obor Indonesia.

Brommelhorster, Jorn (eds.). 2003. The Military an an Economic Actor: Soldiers in Business. New York: Palgrave Macmillan and BICC.

Budiardjo, Miriam. 2000. Dasar Dasar Ilmu Politik. Jakarta: PT. Gramedia Pustaka Utama.

Chrisnandi, Yuddy. 2005. Reformasi TNI; Perspektif Baru Hubungan Sipil-Militer di Indonesia. Jakarta: LP3ES.

Huntington, Samuel P. 2003. Prajurit dan Negara: Teori dan Politik Hubungan Militer-Sipil. Terjemahan Deasy Sinaga. Jakarta: Grasindo.

IPU and DCAF. 2003. Parliamentary Oversight of the Security Sector. Geneva: IPU and DCAF.

Joyce, Peter. 2003. Politics. London: Teach Yourself.

M.D. La Ode. 2006. Peran Militer dalam Ketahanan Nasional; Studi Kasus Bidang Hankam di Indonesia Tahun 1967 - 2000. Jakarta: Pustaka Sinar Harapan.
Moleong, Lexy J. 2007. Metodologi Penelitian Kualitatif. Bandung: PT. Remaja Rosdakarya.

Nainggolan, Poltak Partogi. 2007. "Komando Teritorial dan Budaya Politik Militer dalam Era Reformasi (1998-2006)" dalam Poltak Partogi Nainggolan (eds.). Komando Teritorial dan Budaya Politik TNI dalam Era Reformasi. Jakarta: P3DI Dewan Perwakilan Rakyat Republik Indonesia.

Prihatono, T. Hari., dkk. 2007. Keamanan Nasional: Kebutuhan Membangun Perspektif Integratif Versus Pembiaran Politik dan Kebijakan. Jakarta: Propatria Institute.

Robinson, Richard. 1986. The Rise of Capital. Canberra: Asian Studies Association of Australia.

Rieffel, Lex, dan Jaleswari Pramodhawardani. 2007. Menggusur Bisnis Militer Tantangan Pembiayaan TNI Melalui $A P B N$. Bandung: Mizan.

Said, Salim. 2006. Militer Indonesia dan Politik (Dulu, Kini, dan Kelak). Jakarta: Pustaka Sinar Harapan.

Sanit, Arbi. 1985. Perwakilan Politik di Indonesia. Jakarta: Rajawali.

Siswanto, H.B. 2007. Pengantar Manajemen. Jakarta: PT. Bumi Aksara.

Sukadis, Beni. 2008. Almanak Reformasi Sektor Keamanan Indonesia 2007. Jakarta: Lesperssi dan DCAF.

Surakhmad, Winarno. 1989. Pengantar Penelitian Ilmiah. Bandung : Tarsito

Suryohadiprojo, Sayidiman. 2005. Si Vis Pacem Para Belum; Membangun Pertahanan Negara yang Modern dan Efektif. Jakarta: PT. Gramedia Pustaka Utama.

Turney, Harry Holbert. 1981. The Military. Carolina - USA: University of Carolina Press.

Yulianto, Arif. 2002. Hubungan Sipil Militer di Indonesia Pasca Orba; Ditengah Pusaran Demokrasi. Jakarta: PT. RajaGrafindo Persada. 